JURNAL

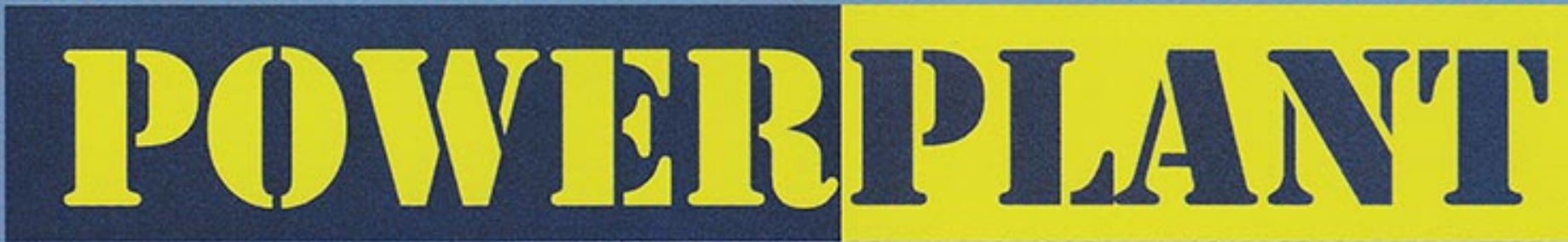

Roswati Nurhasanah

Jasmid Edy

Eza Brian Pradana

\section{Arief Suardi}

Vendy Antono

Al Asyi

Arisma Chairul Syarif Iman Kartolaksono R Jalu Eko Harjono

Nofirman

Yusuf Rasyid

Win Alfalah

Eko Sulistyo

Rahmat Ikhsan

Utami Wahyuningsih

Halim Rusjdi

Eko Sulistiyo

Sahlan

Jumiati

Intan Ratna Sari Yanti

Sri Yayi
Perancangan Boiler Dengan Memanfaatkan Sampah

Kering Untuk Bahan Bakar PLTU Mini 3 kW STT-PLN

Analisis Perbandingan Penggunaan Big Oil Gun dan Tiny Oil Gun terhadap Kosumsi Bahan Bakar Pada Saat Strat Up Unit di PLTU Banten Lontar

Uji Prestasi dan Emisi Diesel Berbahan Bakar Minyak Nabati Murni untuk Pembangkitan Daya di Daerah Terpencil

Pengukuran Suhu Pembakaran di Dalam Boiler : Pirometer Akuistik VS Pirometer Infared

Pengaruh Pemeliharaan Overhoul Turbo Charger

Terhadap Kinerja Mesin Unit VII PLTD Ampenan

Penanggulangan Korosi Pada Pipa Gas Dengan Metode Catodic Protection (Anoda Karbon) PT PGN Solution Area Cengkareng

Analisis Strategi Teknologi PLTS Fotovoltik di Indonesia Terhadap Nilai Eqivalensi dan Pemanfatan Per Wilayah

Pengembangan Model Pembelajaran Berbasis Tutorial Bagi Mahasiswa Teknik Mesin STT PLN

\begin{tabular}{|c|c|c|c|c|c|c|}
\hline III & & $\mathrm{SE}$ & OLAH & INGGI TEV & PLN (STT-PLN) & \\
\hline - $\|||||||||||||||||$ & JURNAL POWERPLANT & VOL. 5 & NO. 1 & HAL, 1.63 & NOVEMBER 2017 & ISSN No :2356-1513 \\
\hline
\end{tabular}




\title{
UJI PRESTASI DAN EMISI DIESEL BERBAHAN BAKAR MINYAK NABATI MURNI UNTUK PEMBANGKITAN DAYA DI DAERAH TERPENCIL
}

\author{
Arisma Chairul Syarif \\ Teknik Mesin STT PLN \\ Email: arisma@sttpln.ac.id \\ Iman Kartolaksono Reksowardojo dan Jalu Eko Harjono \\ Teknik Mesin ITB \\ Email: imankr@itb.ac.id
}

\begin{abstract}
Pure Plant Oil (PPO) such as Pure Coconut Oil (PCO) and Pure Palm Oil (PPaO) could be a solution for electricity problem in remote areas in Indonesia. PCO and PPaO can be used as a fuel for diesel engine to produce electricity. This paper will compare and analyze the performance and emissions of the diesel power plant fueled with diesel fuel, PCO, and PPaO. For performance parameter, brake specific fuel consumption and thermal efficiency of diesel engine by using PPaO and PCO are higher than the diesel fuel, but the brake specific energy consumption are lower than the diesel fuel. That means diesel engine will be more efficient and have lower operational cost by using $\mathrm{PPaO}$ and $\mathrm{PCO}$. For the emission parameters, $\mathrm{CO}_{2}, \mathrm{CO}$, and $\mathrm{CH}$ emissions from $\mathrm{PPaO}$ and $\mathrm{PCO}$ are higher compared to diesel fuel. That means PPO have higher carbon emission than just using conventional diesel fuel. But, there are highly significant difference of less $N O_{X}$ emissions by using PCO and PPaO compared to the diesel fuel. That means it will be better using PPO because diesel engine has lack of high $\mathrm{NO}_{X}$ emissions. These differences of diesel engine performance and emissions by $\mathrm{PPaO}, \mathrm{PCO}$, and diesel fuel are caused by the fuel characteristic differences such as cetane number, calorific value, and viscosity.
\end{abstract}

Keywords: diesel power generation, diesel engine, pure plant oil.

\section{PENDAHULUAN}

Distribusi listrik di Indonesia masih belum merata terutama pada daerah dan pulau terpencil. Bedasarkan data yang didapat dari Kementrian Energi dan Sumber Daya Mineral (ESDM), rasio elektrifikasi dari beberapa provinsi di Indonesia masih di bawah 50\%. Rasio elektrifikasi merupakan perbandingan antara jumlah rumah tangga berlistrik dengan jumlah rumah tangga pada suatu daerah. Artinya, lebih dari 50\% penduduuk di beberapa provinsi di Indonesia belum mendapatkan listrik untuk memenuhi kebutuhan sehari-harinya.

Salah satu alasan dari distribusi listrik yang belum merata adalah tingginya harga dari kabel bawah laut untuk mendistribusikan listrik dari pulau-pulau besar dan juga tingginya harga distribusi bahan bakar ke pulau terpencil. Namun jika kita melihat dari sudut pandang lain, pulau-pulau terpencil di Indonesia memiliki sumber daya alam yang dapat dimanfaatkan seperti kelapa dan kelapa sawit. Sumber daya alam in situ ini dapat dimanfaatkan sebagai bahan bakar Pembangkit Listrik Tenaga Diesel (PLTD). Oleh karena itu perlu dilakukan pengujian pada bahan bakar tersebut dan dibandingkan dengan bahan bakar diesel konvensional seperti minyak solar.

\section{KAJIAN LITERATUR}

Performa atau prestasi dari mesin diesel ditunjukkan untuk mengetahui kualitas dari bahan bakar yang digunakan. Prestasi ini juga ditentukan oleh laju konsumsi bahan bakarnya. Brake Specific Fuel Consumption (BSFC) atau konsumsi bahan bakar spesifik adalah perbandingan laju konsumsi aliran massa bahan bakar yang digunakan dengan daya yang dihasilkan mesin diesel. Konsumsi energi spesifik atau Brake Specific Energy Consumption (BSEC) menunjukan berapa jumlah energi yang diperlukan oleh mesin diesel untuk menghasilkan satu satuan daya. 
Sedangkan efisiensi termal merupakan perbandingan dari energi yang dihasilkan motor dengan potensi energi kimia yang dimiliki bahan bakar.

Reaksi kimia yang terjadi pada proses pembakaran sempurna (stoikiometrik) atau bahan bakar yang berupa hidrokarbon pasti menghasilkan karbon dioksida dan air. Namun, akibat tingginya temperatur area ruang bakar serta proses pembakaran yang berlangsung dengan sangat cepat dan kontak partikel-partikel bahan bakar yang tidak uniform dengan udara menghasilkan campuran bahan bakar dan udara yang bermacam-macam maka dihasilkanlah produk-produk lain seperti karbon monoksida (CO), nitrogen oksida (NOx), hidrokarbon (HC), partikulat, beserta emisi minoritas lainnya. Oleh karena itu emisi yang dihasilkan pada exhaust gas dari mesin diesel juga perlu dianalisis lebih lanjut.

\section{METODE PENELITIAN}

Pengujian dilakukan pada mesin diesel bersilinder tunggal dengan kapasitas 1430cc. Spesifikasi mesin diesel ini dapat dilihat pada Tabel 1. Pada fuel tank ditambahkan fuel heater untuk memanaskan bahan bakar nabati terlebih dahulu sebelum memasuki ruang bakar. Mesin diesel disambungkan pada generator dengan spesifikasi $7 \mathrm{kVA}, 220 \mathrm{~V}$, dan $50 \mathrm{~Hz}$ yang dirangkai pada satu rangkaian generator (genset). Rangkaian generator dan mesin diesel ini dipasang untuk mensuplai beban listrik berupa lampu $500 \mathrm{~W}$ sebanyak 6 buah yang dipasang seri.

Tabel 1 Spesifikasi mesin diesel

\begin{tabular}{|c|c|}
\hline Kapasitas & $3000 \mathrm{~W}$ \\
\hline Model & Lister type \\
\hline Jenis & $\begin{array}{l}\text { Penyemprotan tidak } \\
\text { Langsung (IDI) }\end{array}$ \\
\hline Jumlah silinder & 1 \\
\hline Putaran operasional & $650 \mathrm{rpm}$ \\
\hline Rasio kompresi & $1: 18$ \\
\hline Bore x Stroke & $\begin{array}{l}\begin{array}{l}114,3 \mathrm{~mm} \\
\mathrm{~mm}\end{array}\end{array}$ \\
\hline
\end{tabular}

Mesin diesel diuji pada kecepatan yang konstan yaitu sekitar 650 rpm. Pengujian dilakukan pada mesin diesel yang terhubung pada generator melalui v-belt. Listrik yang dihasilkan generator digunakan untuk memenuhi kebutuhan beban pada lampu yang terpasang. Pengujian dimulai dengan beban bertahap mulai dari $1000 \mathrm{~W}$. Setiap 30 menit beban dinaikkan sebesar $500 \mathrm{~W}$ hingga mencapai beban maksimum yang bisa dihasilkan yaitu $2500 \mathrm{~W}$.

Pada pengujian pertama, diesel diuji dengna menggunakan bahan bakar minyak solar sebagai data perbandingan utama yang nantinya akan dibandingkan dengan penggunaan minyak kelapa sawit murni dan minyak kelapa murni. Data yang diambil berupa konsumsi bahan bakar, emisi, dan opasitas asap dari exhaust gas. Pengujian ini dilakukan pada tiga jenis bahan bakar yaitu minyak solar, minyak kelapa sawit murni (PPaO), dan minyak kelapa murni (PCO). Sebelum pengujian dilakukan, bahan bakar telah terlebih dahulu diuji untuk mengetahui karakteristik bahan bakar tersebut. Pengujian dilakukan di Laboratorium Pusat Penelitian dan Pengembangan Teknologi Minyak Bumi dan Gas Bumi, Lembaga Minyak dan Gas Bumi (Lemigas). Hasil pengujian tersebut dapat dilihat pada Tabel 2.

Tabel 2 Karakteristik Bahan Bakar

\begin{tabular}{|c|c|c|c|c|}
\hline \multirow[b]{2}{*}{$\begin{array}{l}\text { Jenis } \\
\text { Pengujian }\end{array}$} & \multirow[b]{2}{*}{ Unit } & \multicolumn{3}{|c|}{ Hasil Uji } \\
\hline & & $\begin{array}{l}\text { Minyak } \\
\text { Solar }\end{array}$ & PCO & $\mathrm{PPaO}$ \\
\hline $\begin{array}{l}\text { Angka } \\
\text { Setana }\end{array}$ & - & 48,8 & 39,6 & 42,2 \\
\hline \multicolumn{5}{|l|}{ Nilai Kalor } \\
\hline - Net & $\mathrm{MJ} / \mathrm{kg}$ & 38,129 & 33,843 & 35,248 \\
\hline - Gross & $\mathrm{MJ} / \mathrm{kg}$ & 39,061 & 34,375 & 35,352 \\
\hline Berat Jenis & $\mathrm{kg} / \mathrm{m}^{3}$ & 853,9 & 908,2 & 898,5 \\
\hline Viskositas & $\mathrm{cSt}$ & 3,32 & 26,96 & 39,58 \\
\hline
\end{tabular}

\section{HASIL DAN PEMBAHASAN}

Melalui hasil pengujian didapatkan data berupa laju konsumsi bahan bakar dan emisi dalam bentuk persen (\%) dan ppm. Hasil laju konsumsi bahan bakar dikalkulasi untuk mendapatkan hasil uji prestasi yaitu brake specific fuel consumption (bsfc), brake specific energy consumption (bsec), dan efisiensi termal. Sedangkan, hasil uji emisi akan dikonversi dalam bentuk $\mathrm{g} / \mathrm{kWh}$ yang menyatakan banyaknya emisi yang dihasilkan untuk memproduksi listrik sebesar $1 \mathrm{kWh}$. 


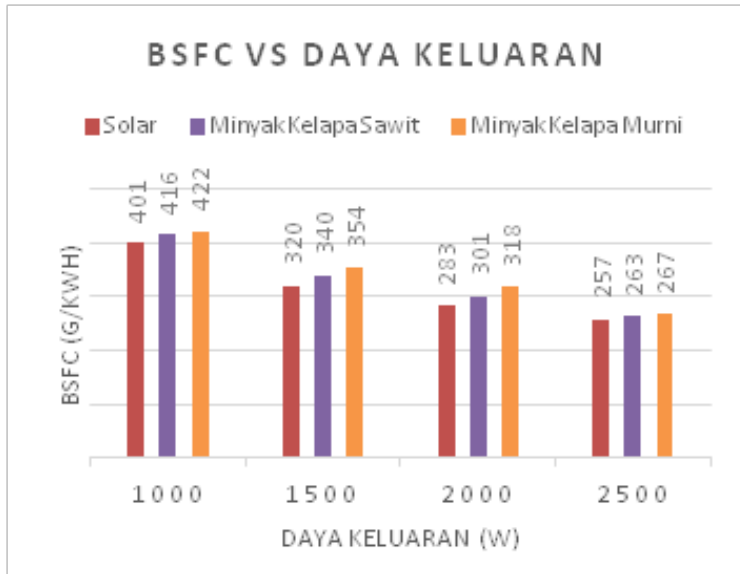

Gambar 1 Perbandingan BSFC terhadap Daya Keluaran

Pada Gambar 1 dapat dilihat perbandingan BSFC minyak kelapa murni (PCO), minyak kelapa sawit murni $(\mathrm{PPaO})$ dan minyak solar. Minyak solar merupakan bahan bakar utama dan dijadikan bahan bakar pembandingnya. Konsumsi bahan bakar spesifik atau BSFC dari minyak kelapa dan minyak kelapa sawit lebih tinggi rata-rata $7,2 \%$ dan $4,7 \%$ daripada solar. Hal itu disebabkan karena massa jenis dari minyak nabati murni tersebut lebih tinggi dibandingkan solar. Selain ditentukan dari nilai massa jenisnya, faktor lain yang mempengaruhi BSFC adalah nilai kalor bahan bakar yang terkandung pada bahan bakar tersebut. Nilai kalor solar lebih tinggi dari PCO dan PpaO sehingga untuk memenuhi kebutuhan daya yang relatif sama, $\mathrm{PCO}$ dan $\mathrm{PPaO}$ membutuhkan jumlah yang lebih banyak dibandingkan minyak solar.

\section{BSEC VS DAYA KELUARAN}

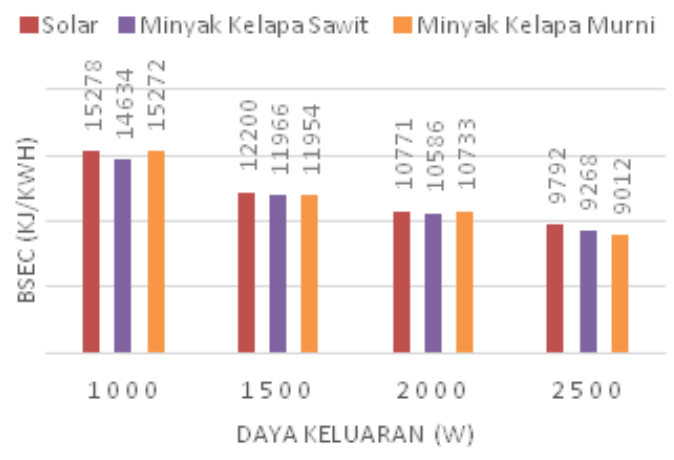

Gambar 2 Perbandingan BSEC terhadap Daya Keluaran

Pada Gambar 2 dapat dilihat perbandingan dari konsumsi energi spesifik minyak kelapa, kelapa sawit, dan solar. Berbeda dengan perbandingan pada konsumsi bahan bakar spesifik atau BSFC, BSEC dari minyak kelapa lebih rendah rata-rata 4,5\% daripada minyak solar, begitupun BSEC dari minyak kelapa sawit lebih rendah rata-rata $3,3 \%$. Semakin rendah nilai BSEC menunjukan bahwa motor bakar torak tersebut memiliki kemampuan yang baik dalam mengubah energi yang dihasilkan pada proses pembakaran menjadi energi mekanik. BSEC yang rendah pada PCO dan $\mathrm{PPaO}$ disebabkan oleh peran oksigen yang terkandung dalam PCO dan PPaO. Dengan adanya oksigen, proses pembakaran lebih mudah terjadi karena ikatan karbon dan oksigen sudah tercampur didalam bahan bakar.

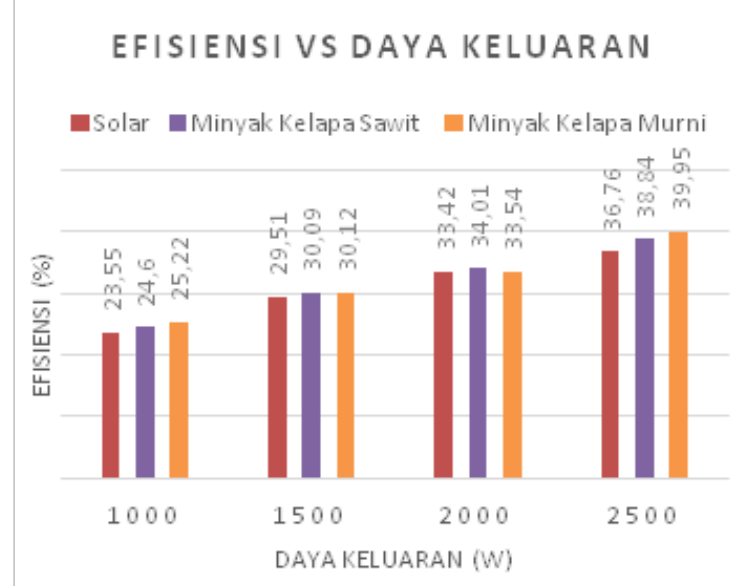

Gambar 3 Perbandingan Efisiensi Termal terhadap Daya Keluaran

Pada Gambar 3 juga dapat dilihat perbandingan dari efisiensi bahan bakar antara minyak kelapa, kelapa sawit, dan solar. Efisiensi dari minyak kelapa dan kelapa sawit lebih tinggi rata-rata 5,1\% dan 3,3\% dibandingkan dengan minyak solar. Penyebab efisiensi yang dihasilkan oleh penggunaan $\mathrm{PCO}$ dan $\mathrm{PPaO}$ lebih baik dari minyak solar adalah nilai kalor dari PCO dan PPaO lebih rendah dibandingkan minyak solar, sehingga energi yang masuk pada sistem semakin rendah namun tetap menghasilkan daya yang sama. Adanya oksigen pada PCO dan PPaO menyebabkan pencampuran bahan bakar dengan udara menjadi lebih mudah sehingga efisiensi termalnya lebih tinggi dibandingkan minyak solar. Selain itu, bilangan setana yang rendah pada PCO dan $\mathrm{PPaO}$ membuat ignition delay sebelum proses pembakaran lebih panjang. Hal ini menyebabkan bahan bakar yang terbakar pada tahap rapid combustion lebih sedikit dan sebagian besar bahan bakar terbakar pada tahap mixed-controlled combustion dan late 
combustion secara perlahan dan menyebabkan temperatur pembakaran yang tinggi akibat jumlah bahan bakar yang terbakar juga lebih banyak. Selain efisiensi, perbedaan waktu pembakaran bahan bakar ini juga mempengaruhi emisi yang dihasilkan yang akan dijelaskan lebih lanjut nantinya.

\section{EMISI CO 2 VS DAYA KELUARAN}

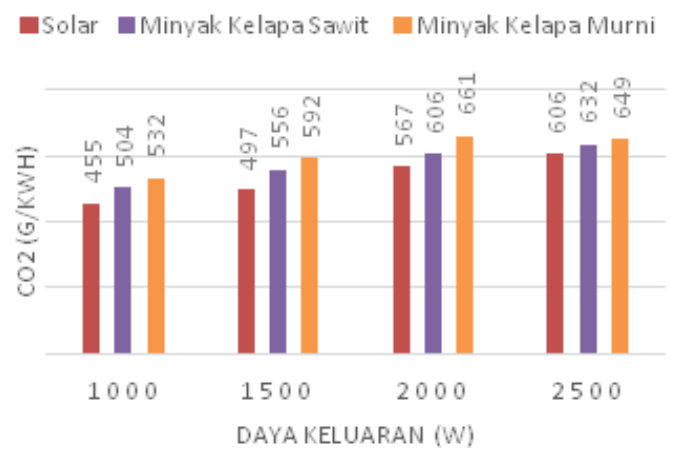

Gambar 4 Perbandingan Emisi $\mathrm{CO}_{2}$ terhadap Daya Keluaran

Pada Gambar 4 dapat dilihat perbandingan dari emisi $\mathrm{CO}_{2}$ motor diesel dengan bahan bakar minyak kelapa, kelapa sawit, dan solar. Emisi $\mathrm{CO}_{2}$ dari minyak kelapa dan kelapa sawit lebih tinggi rata-rata 6,8\% dan 3,3\% dibandingkan dengan minyak solar. Hal ini disebabkan karena nilai kalor pada minyak kelapa sawit murni dan minyak kelapa murni lebih tinggi sehingga untuk menghasilkan daya yang sama membutuhkan jumlah PPO yang lebih banyak.

Namun perbedaan emisi $\mathrm{CO}_{2}$ yang tidak terlalu besar ini disebabkan karena motor diesel yang digunakan beroperasi pada putaran rendah dan berjenis penyemprotan tidak langsung atau indirect injection (IDI). Secara teoritik, diesel jenis IDI memiliki karakteristik pembakaran yang lambat dan bertahap sehingga bahan bakar yang memiliki bilangan setana yang rendah cocok digunakan pada motor diesel jenis IDI, ditambah lagi motor diesel yang digunakan beroperasi pada putaran rendah yaitu $650 \mathrm{rpm}$ sehingga PPO memiliki cukup waktu untuk bercampur baik dengan oksigen dari udara. Selain karena putarannya yang rendah, kandungan oksigen yang terdapat dalam PPO sangat membantu dalam proses pembakaran.

\section{EMISI CO VS DAYA KELUARAN}

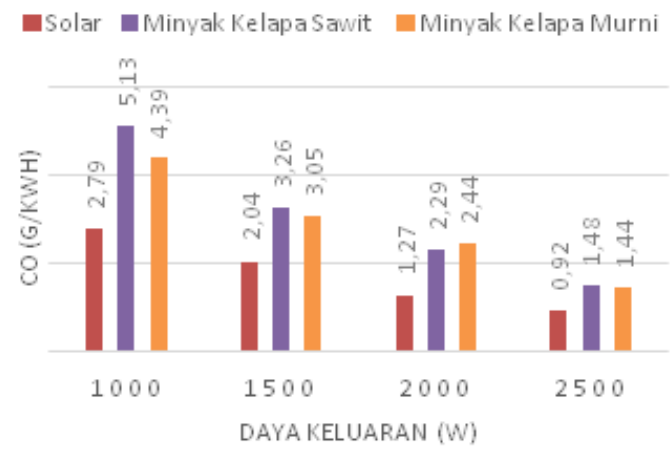

Gambar 5 Perbandingan Emisi CO terhadap Daya Keluaran

Emisi karbon monoksida dari minyak kelapa dan minyak kelapa sawit murni lebih tinggi ratarata 32\% dan 70\% dibandingkan dengan minyak solar. Hal ini disebabkan karena minyak kelapa murni dan minyak kelapa sawit murni memiliki kekentalan yang tinggi sehingga pada proses pengkabutan, butiran bahan bakar yang terbentuk lebih besar. Minyak solar memiliki kekentalan paling rendah sehingga sangat mudah untuk dikabutkan. Butiran bahan bakar minyak solar terbentuk berukuran kecil dan campuran yang terbentuk semakin homogen sehingga emisi CO dari minyak solar merupakan emisi terendah dibandingkan minyak kelapa maupun minyak kelapa sawit.

\section{EMISI CH VS DAYA KELUARAN}

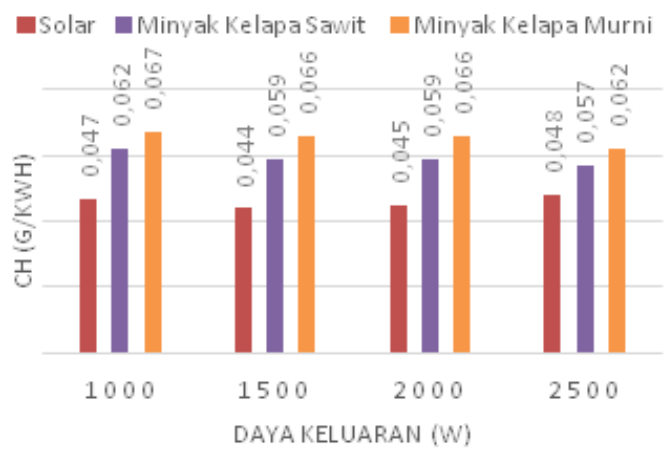

Gambar 6 Perbandingan Emisi CH terhadap Daya Keluaran

Pada Gambar 6 dapat dilihat perbandingan dari emisi hidrokarbon motor diesel dengan menggunakan bahan bakar minyak kelapa, kelapa sawit, dan solar. Emisi hidrokarbon dari minyak kelapa dan kelapa sawit lebih tinggi rata-rata $37,8 \%$ dan $30,8 \%$ dibandingkan minyak solar. Pembentukan emisi $\mathrm{CH}$ atau 
hidrokarbon pada motor diesel tidak lepas dari peran butiran bahan bakar yang terbentuk sesaat setelah proses bahan bakar masuk ke ruang bakar melalui injektor. Kekentalan bahan bakar nabati atau PPO yang lebih tinggi dibandingkan minyak solar membuat proses pengkabutan bahan bakar menjadi kurang baik sehingga emisi hidrokarbon yang terbentuk juga semakin tinggi. Selain pengaruh ukuran butiran bahan bakar, faktor lain yang mempengaruhi tingginya emisi hidrokarbon pada penggunaan PPO adalah bilangan setana.

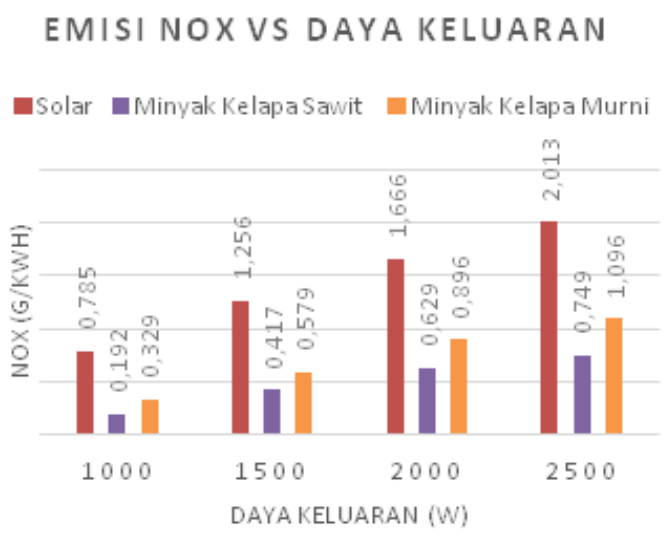

Gambar 7 Perbandingan Emisi $\mathrm{NO}_{\mathrm{x}}$ terhadap Daya Keluaran

Pada Gambar 7 dapat dilihat perbandingan dari emisi nitrogen oksida motor diesel dengan menggunakan bahan bakar minyak kelapa, kelapa sawit, dan solar. Emisi nitrogen oksida dari minyak kelapa lebih rendah rata-rata 210\% dibandingkan dengan minyak solar, begitupun emisi nitrogen oksida dari minyak kelapa sawit lebih rendah rata-rata $117 \%$. Hal itu menandakan bahwa emisi nitrogen oksida yang dihasilkan pada penggunaan minyak solar sangat tinggi yang disebabkan oleh temperatur pembakaran saat menggunakan minyak solar sangat tinggi.

Temperatur ruang bakar yang sangat tinggi ini disebabkan oleh minyak solar yang memiliki bilangan setana dan nilai kalor yang lebih tinggi dibandingkan $\mathrm{PPaO}$ dan $\mathrm{PCO}$ yang membuat pembakaran yang terjadi lebih cepat karena ignition delay dari minyak solar lebih singkat dan membuat sebagian besar bahan bakar terbakar pada tahap rapid combustion dan menghasilkan temperatur yang tinggi karena pelepasan panas terjadi pada titik maksimal. Kenaikan temperatur yang mendadak memicu laju pembentukan nitrogen oksida menjadi lebih cepat maka dari itu emisi nitrogen oksida yang dihasilkan pun meningkat drastis pada penggunaan minyak solar. Rendahnya emisi nitrogen oksida pada penggunaan PPO disebabkan oleh bahan bakar yang sebagian besar terbakar pada tahap mixed-controlled combustion. Pada tahap ini pembakaran terjadi secara lambat dan bertahap sehingga pelepasan panas yang terjadi tidak setinggi pada tahap rapid combustion sehingga membuat temperatur ruang bakar saat itu tidak meningkat secara drastis dan membuat emisi nitrogen oksida yang dihasilkan juga lebih rendah.

\section{OPASITAS ASAP VS DAYA} KELUARAN

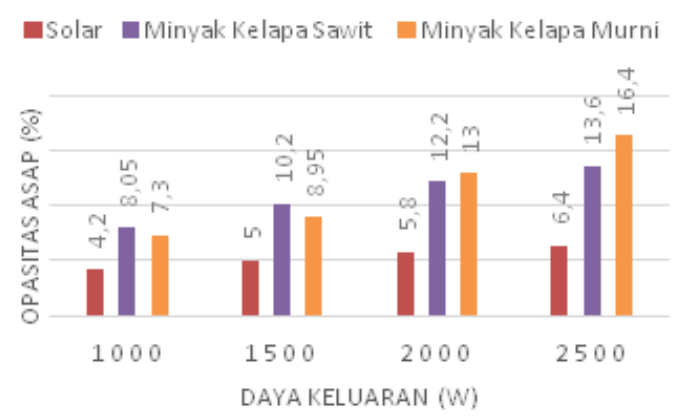

Gambar 8 Perbandingan Opasitas Asap terhadap Daya Keluaran

Pada Gambar IV.15 dan Gambar IV.8 dapat dilihat perbandingan dari opasitas asap motor diesel dengan menggunakan bahan bakar minyak kelapa, kelapa sawit, dan solar. Opasitas asap dari minyak kelapa lebih tinggi rata-rata $76,2 \%$ dibandingkan dengan minyak solar, begitupun opasitas asap dari minyak kelapa sawit lebih tinggi rata-rata 93,8\%. Kekentalan minyak solar yang rendah membuat proses pengkabutan bahan bakar menjadi lebih mudah sehingga saat memasuki ruang bakar, bahan bakar yang masuk sudah berupa butiran bahan bakar yang berukuran lebih kecil dan mudah terbakar. Bilangan setana minyak solar yang lebih tinggi juga memiliki peran pada saat proses pembakaran.

Minyak solar yang memiliki bilangan setana lebih tinggi mengalami ignition delay yang pendek, ditambah dengan butiran bahan bakar yang lebih kecil menyebabkan banyak minyak solar yang terbakar pada tahap rapid combustion. Hal ini mengakibatkan kenaikan temperatur ruang bakar yang drastis karena jumlah bahan bakar yang terbakar lebih banyak dan meningkatkan temperatur pembakaran. Dengan tingginya temperatur ruang bakar pada 
tahap sebelumnya membuat pembakaran pada tahap mixed-controlled combustion menjadi lebih mudah sehingga sisa bahan bakar yang belum terbakar pada tahap rapid combustion bisa terbantu untuk bereaksi dengan udara dan terbakar sehingga pembakaran yang terjadi lebih sempurna dan menghasilkan asap yang rendah.

Hal ini pula yang menyebabkan opasitas asap pada penggunaan $\mathrm{PPaO}$ dan $\mathrm{PCO}$ menjadi sangat tinggi jika dibandingkan dengan penggunaan minyak solar. Tingginya opasitas asap pada penggunaan $\mathrm{PPaO}$ dan $\mathrm{PCO}$ disebabkan oleh kekentalan bahan bakar yang lebih tinggi dan angka setana yang lebih rendah. Kekentalan bahan bakar yang tinggi membuat proses pengkabutan bahan bakar menjadi lebih sulit karena bahan bakar tidak terkabutkan secara sempurna dan membuat butiran bahan bakar yang terbentuk memiliki ukuran yang lebih besar sehingga proses pembakaran yang terjadi kurang sempurna.

\section{KESIMPULAN}

Melalui hasil penelitian ini dapat disimpulkan bahwa dari parameter prestasi, mesin diesel yang menggunakan bahan bakar minyak nabati murni (PPO) yaitu minyak kelapa murni (PCO) dan minyak kelapa sawit murni (PPaO) memiliki konsumsi bahan bakar spesifik (BSFC) dan efisiensi termal yang lebih besar dibandingkan dengan mesin diesel yang menggunakan bahan bakar minyak solar. Selain itu, konsumsi energi spesifik (BSEC) dari penggunaan PPO pada mesin diesel juga lebih rendah dibandingkan dengan penggunaan minyak solar. Hal ini menunjukkan bahwa penggunaan bahan bakar nabati pada mesin diesel akan lebih menguntungkan karena konsumsi bahan bakar yang lebih sedikit dan efisiensi yang dihasilkan oleh mesin diesel lebih besar.

Dari parameter emisi yang dihasilkan, mesin diesel yang menggunakan bahan bakar nabati menghasilkan emisi karbon dioksida, karbon monoksida, dan hidrokarbon yang lebih besar dibandingkan mesin diesel yang menggunakan bahan bakar minyak solar. Hal ini disebabkan karena perbedaan angka setana pada bahan bakar yang digunakan. Akan tetapi, terlihat perbedaan yang signifikan pada emisi nitrogen oksida (NOx) yang dihasilkan. Emisi NOx yang dihasilkan dari mesin diesel yang berbahan bakar PPO jauh lebih rendah dibandingkan dengan mesin diesel berbahan bakar minyak solar. Hal ini menjadi nilai tambah bagi penggunaan bahan nabati sebagai bahan bakar alternatif pengganti bahan bakar diesel konvensional karena dapat mengurangi emisi NOx di udara yang sebagian besar dihasilkan oleh penggunaan bahan bakar diesel konvensional seperti minyak solar.

\section{REFERENSI}

1. Perusahaan Listrik Negara (PLN) Statistics and Direktorat Jendral Ketenagalistrikan (DJK) in 2012 from Pusat Data dan Informasi Kementrian Energi dan Sumber Daya Mineral (Pusdatin ESDM).

2. Pusat Data dan Sistem Informasi Pertanian, Analisis Harga Komoditas Pertanian Vol. 11 No. 1 Tahun 2014 Sekertariat Jendral Kementerian Pertanian, 2014.

3. Klell Manfred, Lectures Based on Script of the Institute for Internal Combustion Engine and Thermodynamics, Technical Univeristiy Graz dan Jenbacher System, Graz, 1998.

4. Breinesberger Josef, Pure Plant Oil a New Fuel?. Pure Plant Oil as Fuel Technical Aspect and Legislative Context, Agriforenergy, 2011. 